\title{
Modeling the Relationship of Tomato Yield Parameters with Deficit Irrigation at Different Growth Stages
}

\author{
Xuelian Jiang, Yueling Zhao ${ }^{1}$, Rui Wang, and Sheng Zhao
}

Key Laboratory of Biochemistry and Molecular Biology in Universities of Shandong, Weifang University, Weifang 261061

Additional index words. deficit irrigation, evapotranspiration, fruit yield parameters, tomato, water-yield model

\begin{abstract}
Greenhouse experiments were conducted in 2017 and 2018 to investigate quantitative relationships between tomato yield parameters and deficit irrigation at different growth stages. Tomato plants received one of three irrigation treatments (full irrigation, 2/3, and 1/3 full irrigation) at flowering and fruit development (stage 2) and at fruit maturation (stage 3); no deficit irrigation treatments were applied at stage 1 during either season. We used linear regression to investigate how well the yield parameters such as whole-plant yield $(Y)$, single-fruit weight $(y)$, fruit diameter $(D)$, and length $(L)$ were correlated with seasonal evapotranspiration $(E T)$ under different deficit irrigation treatments. Six water-yield models (Blank, Jensen, Singh, Stewart, Minhas, and Rao models) were used to predict the tomato yield parameters with deficit irrigation at different growth stages. The results showed that deficit irrigation at each growth stage significantly decreased $E T, Y, y, L$, and $D$, but not $T_{1}(2 / 3$ full irrigation at flowering and fruit development). $T_{1}$ produced higher water use efficiency $(W U E)$ with no significant decrease in yield parameters, indicating that an acceptable balance between high $W U E$ and yield can be obtained with an appropriate water deficit at stage 2 . Relative $Y, y, D$, and $L$ increased linearly as relative seasonal $E T$ increased. Water deficit sensitivity indexes calculated by the six different water-yield models showed that $Y, y, D$, and $L$ were more sensitive to water deficit at stage 2 than at stage 3. The values of $Y$ calculated by the Minhas and Singh models were similar to the observed values. The Minhas model provided good estimates of $L$ and $D$, and the Blank model is recommended for calculating $y$ when there is a water deficit at different growth stages. The water-yield models can be used to optimize irrigation water management and provide a sound basis for efficient tomato production.
\end{abstract}

Tomatoes are an important economic crop in China, and they have the greatest planting area of all vegetable crops worldwide (Favati et al., 2009; Ho et al., 1996). They require large quantities of water, with seasonal water consumption of $\approx 500$ to $600 \mathrm{~mm}$ supplied by irrigation in greenhouses (Giuliani et al., 2016). A water-saving irrigation strategy that allows the crop to maintain satisfactory yields and produce high-quality fruits will preserve the limited resource (Parry et al., 2005; Topcu et al., 2007), especially in the North China Plain, where water is scarce. Tomato production has increased in recent years, and improving water use efficiency $(W U E)$ may be more profitable to farmers in a water-scarce region than maximizing tomato

Received for publication 29 Apr. 2019. Accepted for publication 4 June 2019.

We are grateful for research grants from the National Natural Science Foundation of China (51709203), the Natural Science Foundation of Shandong Province (ZR2017BEE079), the Key Research and Development Plan of Shandong (2018GNC2306).

${ }^{1}$ Corresponding author. E-mail: yuelingzhao@163. com.

This is an open access article distributed under the CC BY-NC-ND license (https://creativecommons. org/licenses/by-nc-nd/4.0/). production. A reasonable deficit irrigation strategy subjects crops to some degree of water deficit but maintains satisfactory yield (Pereira et al., 2002). Such a strategy saves significant quantities of irrigation water, reduces production costs, optimizes $W U E$, and reduces the leakage of nutrients and pesticides to groundwater (Pulupol et al., 1996). Many studies have shown that some degree of deficit irrigation can increase $W U E$ and improves tomato quality (Chen et al., 2013, 2014; Favati et al., 2009; Wang et al., 2011a; Wang et al., 2015). However, water stress can result in smaller fruit size, lower yield, earlier plant senescence, and increased vulnerability to various diseases (Favati et al., 2009; Hanson et al., 2006; Pulupol et al., 1996). The sensitivity of crop yield to water stress varies at different stages of plant growth. Doorenbos and Kassam (1979) found that tomato yield was most sensitive to water stress at the flowering stage. Wang et al. (2011a) found that water stress at the fruit maturation and harvesting stages in a greenhouse in arid northwest China significantly affected tomato yield. Chen et al. (2014) found that tomato yield was sensitive to water deficit at the flowering, fruit development, and fruit ripening stages. However, the effects of deficit irrigation on both tomato yield and water consumption are poorly understood due to the complexity of the relationship, despite much previous research
(Chen et al., 2014; Favati et al., 2009; Marouelli and Silva, 2007; Patanè and Cosentino, 2010; Renquist and Reid, 2001). Therefore, it is important to develop a deficit irrigation strategy for tomato crops that provides an optimal irrigation level at optimal times.

The conflicting demands of high tomato yield and reduced water consumption must be considered when determining precise deficit irrigation management. Stewart et al. (1977) discovered a linear relationship between relative reduction in tomato yield $(Y)$ and seasonal evapotranspiration (ET) deficit. Other studies have found positive linear relationships between tomato yield and seasonal ET (Chen et al., 2013; Kuscu et al., 2014; Zheng et al., 2013). To describe the effects of both irrigation level and application scheduling on yield, the dated crop water production function (DCWPF) model was developed to quantify the functional relationships between crop yield and ET or ET deficit (Rao et al., 1988). The DCWPF model can apply additive and multiplicative forms to quantify the relationships between the final crop yield and ET or ET deficit either at each growth stage or for the whole growth period; furthermore, it can be used to determine a deficit irrigation strategy and improve irrigation WUE. Typical additive DCWPF models are the Blank (Blank, 1975), Stewart (Stewart et al., 1976), and Singh (Singh et al., 1987) models. Multiplicative DCWPF models include the Jensen (Jensen, 1968), Minhas (Minhas et al., 1974), and Rao (Rao et al., 1988) models. The DCWPF model provides good estimates of crop yield and optimizes irrigation water management during the whole growing season when there is insufficient water available (Chen et al., 2014). The aforementioned DCWPF model is widely used to estimate the relationships between water deficit at different growth stages and the grain yield of cereal crops such as rice, maize, and wheat (Igbadun et al., 2007; Li et al., 2011; Paredes et al., 2014; Zhang et al., 1999; Zhang and Oweis, 1999).

Because the fruit development and fruit ripening stages overlap, ripe tomatoes are harvested many times. Few studies have used the DCWPF model to estimate total tomato yield with deficit irrigation at different growth stages (Chen et al., 2014; Xu et al., 2001) or to estimate other yield parameters such as singlefruit weight, single-fruit diameter, and singlefruit length. The objectives of this study were to determine the relationship between tomato yield parameters and seasonal $E T$ with deficit irrigation at different growing stages and to model the response of tomato yield parameters to water deficit using the Blank, Jensen, Singh, Stewart, Minhas, and Rao models. This study aimed to optimize irrigation water management and achieve efficient tomato production that can balance yield with $W U E$.

\section{Materials and Methods}

\section{Experimental setup}

The greenhouse experiments were conducted during two planting seasons at Weifang 
University (lat. $36^{\circ} 71^{\prime} \mathrm{N}$, long. $119^{\circ} 36^{\prime} \mathrm{E}$, altitude $27.03 \mathrm{~m}$ ) and at Gaomi experimental station (lat. $36^{\circ} 38^{\prime} \mathrm{N}$, long. $112^{\circ} 56^{\prime} \mathrm{E}$, altitude $26.03 \mathrm{~m}$ ) in Weifang City, Shandong Province. The experimental sites are in a subhumid climate zone. The mean annual precipitation is $646 \mathrm{~mm}$, and the mean annual temperature is $11.7^{\circ} \mathrm{C}$. The meteorological variables during the experimental period were measured using a standard automatic weather station (HOBO; Onset Computer Corp., Bourne, MA) placed at the center of the greenhouse. Solar radiation $\left(R_{a}\right)$, air temperature $\left(T_{a}\right)$, and relative humidity $(R H)$ were continuously observed. The mean daily values of the meteorological variables at different

growing stages during the two seasons are provided in Table 1.

The tomato (Solanum lycopersicum L.) varieties were Baoli 3 in 2017 and Xingtian 576 in 2018. The tomato plants, which had similar heights, were transplanted to plastic pots on 8 Apr. 2017 and 27 June 2018; they were uprooted on 30 July 2017 and 13 Oct. 2018. The pot height was $21 \mathrm{~cm}$, the top diameter was $30 \mathrm{~cm}$, and the bottom diameter was $20 \mathrm{~cm}$. The pots were filled with light sandy loam that had been air-dried and sieved with a $5-\mathrm{mm}$ sieve. The weight of the soil in each pot was $6 \mathrm{~kg}$, bulk density values were $1.38 \mathrm{~g} / \mathrm{cm}^{3}$ (2017) and $1.40 \mathrm{~g} / \mathrm{cm}^{3}$ (2018), and field water capacity $(F C)$ values were

Table 1 . Mean daily average solar radiation $\left(R_{a}, \mathrm{~W} / \mathrm{m}^{2}\right)$, relative humidity $(R H)$, and air temperature $\left(T_{a},{ }^{\circ} \mathrm{C}\right)$ at different growing stages of tomatoes during two seasons.

\begin{tabular}{llccc}
\hline Crop season & \multicolumn{1}{c}{ Growing stages } & $R_{a}$ & $R H$ & $T_{a}$ \\
\hline 2017 & Stage 1 (8-25 Apr.) & 167.10 & 0.55 & 17.99 \\
& Stage 2 (26 Apr.-25 June) & 162.46 & 0.59 & 22.90 \\
& Stage 3 (26 June-30 July) & 128.27 & 0.81 & 29.43 \\
2018 & Whole season (8 Apr.-30 July) & 152.69 & 0.65 & 24.13 \\
& Stage 1 (27 June-8 July) & 107.88 & 0.77 & 27.82 \\
& Stage 2 (9 July-27 Aug.) & 109.16 & 0.79 & 29.93 \\
& Stage 3 (28 Aug.-13 Oct.) & 105.16 & 0.78 & 20.13 \\
& Whole season (27 June-13 Oct.) & 107.30 & 0.78 & 25.47 \\
\hline
\end{tabular}

Table 2. Description of tomato growth stages and irrigation treatments.

\begin{tabular}{ll}
$\begin{array}{l}\text { Growing } \\
\text { stage/treatment }\end{array}$ & \multicolumn{1}{c}{ Description } \\
\hline Stage 1 & Seedling stage (from transplant to first fruit set) \\
Stage 2 & Flowering and fruit development (from first fruit set to first fruit maturity) \\
Stage 3 & $\begin{array}{c}\text { Fruit maturation stage (from first fruit maturity to uprooting crops after } \\
\text { all fruit is harvested) } \\
\\
\mathrm{T}_{1}\end{array}$ \\
$\mathrm{~T}_{2}$ & $1 / 3$ full irrigation at stage 2 and full irrigation at stage 3 \\
$\mathrm{~T}_{3}$ & $2 / 3$ full irrigation at stage 2 and full irrigation at stage 3 \\
$\mathrm{~T}_{4}$ & $1 / 3$ full irrigation at stage 3 and full irrigation at stage 2 \\
$\mathrm{~T}_{5}$ & $2 / 3$ full irrigation at stages 2 and 3 \\
$\mathrm{~T}_{6}$ & $2 / 3$ full irrigation at stage 2 and $1 / 3$ full irrigation at stage 2 \\
$\mathrm{~T}_{7}$ & $1 / 3$ full irrigation at stage 2 and $2 / 3$ full irrigation at stage 3 \\
$\mathrm{~T}_{8}$ & $1 / 3$ full irrigation at stages 2 and 3 \\
$\mathrm{CK}$ & Full irrigation, upper soil water content $90 \pm 2 \%$ field capacity, lower soil \\
& water content $75 \pm 2 \%$ field capacity \\
\hline
\end{tabular}

$0.29 \mathrm{~cm}^{3} / \mathrm{cm}^{3}$ (2017) and $0.30 \mathrm{~cm}^{3} / \mathrm{cm}^{3}$ (2018). Three irrigation treatments (full irrigation, $2 / 3$ full irrigation, and $1 / 3$ full irrigation) were applied at flowering and fruit development (stage 2) and at fruit maturation (stage 3), resulting in a total of nine irrigation treatments (Table 2). No significant effect was found on tomato yield for different irrigation levels at the seedling stage (stage 1) (Chen et al., 2013); therefore, no deficit irrigation treatments were applied at stage 1 during either season. Each treatment had eight replicates and was arranged in a randomized complete block design. The full irrigation treatment $(\mathrm{CK})$ was used to irrigate to $90 \pm 2 \% F C$ when the soil water content had decreased to $75 \pm 2 \% F C$ (Chen et al., 2013). The irrigation amount and time of application for different treatments are shown in Table 3. Each pot was fertilized with $0.6 \mathrm{~g}$ nitrogen $(\mathrm{N}), 0.6 \mathrm{~g}$ phosphorus $\left(\mathrm{P}_{2} \mathrm{O}_{5}\right)$, and $0.3 \mathrm{~g}$ potassium $\left(\mathrm{K}_{2} \mathrm{O}\right)$ as the base fertilizer and top-dressed with $0.6 \mathrm{~g} \mathrm{~N}$ and $0.3 \mathrm{~g} \mathrm{~K}_{2} \mathrm{O}$ on 10 June 2017 and 10 Aug. 2018.

\section{Measurements and methods}

Evapotranspiration, yield parameters, and water use efficiency. The daily ET of each plant with different treatments was calculated using the soil water balance method (Qiu et al., 2017, 2018):

$$
E T_{i}=\left(W_{i-1}-W_{i}\right) / \rho+\left(I-D_{a}\right)
$$

where $E T_{i}$ is the $E T$ per plant at the end of day $i(\mathrm{~L} / \mathrm{d}) ; W_{i-1}$ and $W_{i}$ are the weights of each pot at the end of days $i-1$ and $i(\mathrm{~g}) ; \rho$ is the water bulk density $(1000 \mathrm{~g} / \mathrm{L}) ; I$ is the irrigation amount (L); and $D_{a}$ is the drainage amount (L).

Each pot was weighed daily using an electronic scale with $0.1 \mathrm{-g}$ precision at 1800 HR. For each irrigation event, a plastic bottle was installed underneath each pot to collect the drainage water, and $D_{a}$ was measured using a measuring cylinder.

The tomato fruit were harvested four times during the fruit maturation stage. For

Table 3. Irrigation amount $(I, \mathrm{~L})$, total evapotranspiration $(E T, \mathrm{~L})$, and daily average $E T$ (Daily $E T, \mathrm{~L} / \mathrm{d})$ of tomato plants for different treatments during two seasons.

\begin{tabular}{|c|c|c|c|c|c|c|c|c|c|c|c|c|c|}
\hline \multirow[b]{2}{*}{ Crop season } & \multirow[b]{2}{*}{ Treatments } & \multicolumn{3}{|c|}{ Stage 1} & \multicolumn{3}{|c|}{ Stage 2} & \multicolumn{3}{|c|}{ Stage 3} & \multicolumn{3}{|c|}{ Total season } \\
\hline & & $E T$ & Daily $E T$ & $I$ & $E T$ & Daily $E T$ & $I$ & $E T$ & Daily $E T$ & $I$ & $E T$ & Dail & t \\
\hline \multirow[t]{9}{*}{2017} & $\mathrm{~T}_{1}$ & $1.06 \mathrm{a}$ & 0.06 & 0.95 & $3.79 \mathrm{~b}$ & 0.08 & 1.80 & $4.55 \mathrm{ab}$ & 0.10 & 3.78 & $9.40 \mathrm{c}$ & 0.08 & 6.53 \\
\hline & $\mathrm{T}_{2}$ & $1.05 \mathrm{a}$ & 0.06 & 0.90 & $2.28 \mathrm{c}$ & 0.05 & 3.60 & $4.12 \mathrm{~b}, \mathrm{c}$ & 0.09 & 3.78 & $7.45 \mathrm{e}, \mathrm{f}$ & 0.07 & 8.28 \\
\hline & $\mathrm{T}_{3}$ & $1.07 \mathrm{a}$ & 0.06 & 0.92 & $5.53 \mathrm{a}$ & 0.11 & 5.40 & $2.50 \mathrm{e}$ & 0.05 & 2.52 & $10.48 \mathrm{~b}$ & 0.09 & 8.84 \\
\hline & $\mathrm{T}_{4}$ & $1.11 \mathrm{a}$ & 0.07 & 0.93 & $5.61 \mathrm{a}$ & 0.11 & 5.40 & $3.77 \mathrm{c}$ & 0.08 & 1.26 & $9.09 \mathrm{c}, \mathrm{d}$ & 0.08 & 7.59 \\
\hline & $\mathrm{T}_{5}$ & $1.15 \mathrm{a}$ & 0.07 & 0.93 & $3.80 \mathrm{~b}$ & 0.08 & 3.60 & $3.33 \mathrm{~d}$ & 0.07 & 2.52 & $8.27 \mathrm{~d}, \mathrm{e}$ & 0.07 & 7.05 \\
\hline & $\mathrm{T}_{6}$ & $1.18 \mathrm{a}$ & 0.07 & 0.92 & $3.83 \mathrm{~b}$ & 0.08 & 3.60 & $2.14 \mathrm{e}$ & 0.05 & 1.26 & $7.15 \mathrm{f}$ & 0.06 & 5.78 \\
\hline & $\mathrm{T}_{7}$ & $1.13 \mathrm{a}$ & 0.07 & 0.91 & $2.23 \mathrm{c}$ & 0.05 & 1.80 & $3.17 \mathrm{~d}$ & 0.07 & 2.52 & $6.52 \mathrm{f}$ & 0.06 & 5.23 \\
\hline & $\mathrm{T}_{8}$ & $1.19 \mathrm{a}$ & 0.07 & 0.89 & $2.21 \mathrm{c}$ & 0.04 & 1.80 & $2.09 \mathrm{e}$ & 0.05 & 1.26 & $5.49 \mathrm{~g}$ & 0.05 & 3.95 \\
\hline & $\mathrm{CK}$ & $1.10 \mathrm{a}$ & 0.07 & 0.90 & $5.67 \mathrm{a}$ & 0.11 & 5.40 & $4.84 \mathrm{a}$ & 0.11 & 3.78 & $11.61 \mathrm{a}$ & 0.10 & 10.08 \\
\hline \multirow[t]{9}{*}{2018} & $\mathrm{~T}_{1}$ & $2.30 \mathrm{a}$ & 0.15 & 1.40 & $4.29 \mathrm{~b}$ & 0.09 & 2.08 & $2.85 \mathrm{~b}$ & 0.06 & 2.70 & $9.44 \mathrm{c}$ & 0.09 & 8.15 \\
\hline & $\mathrm{T}_{2}$ & $2.30 \mathrm{a}$ & 0.15 & 1.40 & $2.32 \mathrm{c}$ & 0.05 & 4.05 & $2.83 \mathrm{~b}$ & 0.06 & 2.70 & $8.14 \mathrm{e}$ & 0.08 & 6.18 \\
\hline & $\mathrm{T}_{3}$ & $2.31 \mathrm{a}$ & 0.15 & 1.40 & $5.87 \mathrm{a}$ & 0.12 & 5.82 & $2.32 \mathrm{c}$ & 0.05 & 1.80 & $10.49 \mathrm{~b}$ & 0.10 & 9.02 \\
\hline & $\mathrm{T}_{4}$ & $2.32 \mathrm{a}$ & 0.16 & 1.40 & $5.82 \mathrm{a}$ & 0.12 & 5.82 & $2.15 \mathrm{c}, \mathrm{d}$ & 0.05 & 0.90 & $10.29 \mathrm{~b}$ & 0.09 & 8.12 \\
\hline & $\mathrm{T}_{5}$ & $2.39 \mathrm{a}$ & 0.16 & 1.40 & $4.11 \mathrm{~b}$ & 0.08 & 4.05 & $2.18 \mathrm{c}$ & 0.05 & 1.80 & $8.68 \mathrm{~d}$ & 0.08 & 7.25 \\
\hline & $\mathrm{T}_{6}$ & $2.11 \mathrm{a}$ & 0.14 & 1.40 & $4.27 \mathrm{~b}$ & 0.09 & 4.05 & $1.84 \mathrm{~d}, \mathrm{e}$ & 0.04 & 0.90 & $8.22 \mathrm{e}$ & 0.08 & 6.35 \\
\hline & $\mathrm{T}_{7}$ & $2.26 \mathrm{a}$ & 0.15 & 1.40 & $2.34 \mathrm{c}$ & 0.05 & 2.08 & $1.82 \mathrm{de}$ & 0.04 & 1.80 & $7.15 \mathrm{f}$ & 0.07 & 5.28 \\
\hline & $\mathrm{T}_{8}$ & $2.30 \mathrm{a}$ & 0.15 & 1.40 & $2.39 \mathrm{c}$ & 0.05 & 2.08 & $1.69 \mathrm{f}$ & 0.04 & 0.90 & $6.05 \mathrm{~g}$ & 0.06 & 4.38 \\
\hline & $\mathrm{CK}$ & $2.43 \mathrm{a}$ & 0.16 & 1.40 & $5.99 \mathrm{a}$ & 0.12 & 5.82 & $3.18 \mathrm{a}$ & 0.07 & 2.70 & $11.60 \mathrm{a}$ & 0.11 & 9.92 \\
\hline
\end{tabular}

Data followed by different letters for each season are significantly different at $P<0.05$ according to Duncan's multiple range tests. 
each plant, every fruit was weighed to calculate the mean fruit weight $(y)$ and the wholeplant yield $(Y)$. The diameter $(D)$ and length $(L)$ of each fruit were measured using a Vernier caliper. WUE $\left(\mathrm{kg} / \mathrm{m}^{3}\right)$ was the ratio of the whole-plant yield to seasonal ET.

Water-yield model descriptions. The dated crop water production functions were developed to describe the water-yield relationship. They quantified the relationship between yield and water deficit at specific growth stages. We used the additive models (Blank, Stewart, and Singh) and the multiplicative models (Jensen, Minhas, and Rao) to represent the relationships between crop yield and water deficit at different growth stages.

The Blank model (Blank, 1975) equation is:

$$
\frac{Q_{d}}{Q_{c}}=\sum_{i=1}^{n} A_{i}\left(\frac{E T_{d i}}{E T_{c i}}\right)
$$

where $Q_{d}$ represents the fruit yield parameters $(Y, y, D$, and $L)$ for different deficit irrigation treatments; $Q_{c}$ represents the fruit yield parameters $(Y, y, D$, and $L)$ with the full irrigation treatment; $E T_{d i}$ is $E T$ at the $i$ th growth stage with the deficit irrigation treatment; $E T_{c i}$ is $E T$ at the $i$ th growth stage with the full irrigation treatment; $A_{i}$ is Blank's water deficit sensitivity index; and $n$ is the number of growth stages (in this study, $\mathrm{n}=2$ ).

The Stewart model (Stewart et al., 1976) equation is:

$$
\frac{Q_{d}}{Q_{c}}=1-\sum_{i=1}^{n} B_{i}\left(1-\frac{E T_{d i}}{E T_{c i}}\right)
$$

where $B_{i}$ is Stewart's water deficit sensitivity index.

The Singh model (Singh et al., 1987) equation is:

$$
\frac{Q_{d}}{Q_{c}}=\sum_{i=1}^{n} C_{i}\left(1-\left(1-\frac{E T_{d i}}{E T_{c i}}\right)^{2}\right)
$$

where $C_{i}$ is Singh's water deficit sensitivity index.

The Jensen model (Jensen, 1968) equation is:

$$
\frac{Q_{d}}{Q_{c}}=\prod_{i=1}^{n}\left(\frac{E T_{d i}}{E T_{c i}}\right)^{\lambda_{i}}
$$

where $\lambda_{i}$ is Jensen's water deficit sensitivity index.

The Rao model (Rao et al., 1988) equation is:

$$
\frac{Q_{d}}{Q_{c}}=\prod_{i=1}^{n}\left(1-\gamma_{i}\left(1-\frac{E T_{d i}}{E T_{c i}}\right)\right)
$$

where $\gamma_{i}$ is Rao's water deficit sensitivity index.

The Minhas model (Minhas et al., 1974) equation is:

$$
\frac{Q_{d}}{Q_{c}}=\prod_{i=1}^{n}\left(1-\left(1-\frac{E T_{d i}}{E T_{c i}}\right)^{2}\right)^{\delta_{i}}
$$

where $\delta_{i}$ is Minhas's water deficit sensitivity index.

\section{Statistical analysis and evaluation of model performance}

We used SPSS 13.0 version (SPSS Inc., Chicago, IL) to perform a one-way analysis (ANOVA) of the differences in ET, WUE, and fruit yield parameters using different irrigation treatments. Differences were considered significant at $P<0.05$.

The water deficit sensitivity index for each model was estimated using the observed data for 2017. Each water-yield model except the Rao model was transformed into a multiple linear function of relative fruit yield parameters $\left(Q_{d} / Q_{c}\right)$ and relative $E T\left(E T_{d i} /\right.$ $\left.E T_{c i}\right)$ or ET deficit $\left(1-E T_{d i} / E T_{c i}\right)$. The water deficit sensitivity indexes were defined as the coefficients of the multiple linear functions, which were calculated by multiple linear regressions between the observed $Q_{d} / Q_{c}$ and $E T_{d i} / E T_{c i}$ or $1-E T_{d i} / E T_{c i}$. The water deficit sensitivity index of the Rao model was obtained by nonlinear regression.

The performances of different water-yield models estimating fruit yield parameters $\left(E_{i}\right)$ were evaluated using the linear regression between estimated and observed values $\left(Q_{i}\right)$; furthermore, corresponding coefficients of determination $\left(\mathrm{R}^{2}\right)$ were compared. Three statistical indicators of estimation errors included the mean absolute bias error (MAE), root mean square error (RMSE), and modified coefficient of efficiency $\left(E_{1}\right)$, which were calculated by (Legates and McCabe, 1999):

$$
\begin{aligned}
M A E & =\frac{1}{n} \sum_{i=1}^{n}\left|E_{i}-Q_{i}\right| \\
R M S E & =\left[\frac{1}{n} \sum_{i=1}^{n}\left(Q_{i}-E_{i}\right)^{2}\right]^{\frac{1}{2}} \\
E_{1} & =1.0-\frac{\sum_{i=1}^{n}\left|Q_{i}-E_{i}\right|}{\sum_{i=1}^{n}\left|Q_{i}-\bar{Q}\right|}
\end{aligned}
$$

where $\bar{Q}$ is the mean of the observed value.

\section{Results and Discussion}

Effects of deficit irrigation on evapotranspiration. Table 3 shows the total wholeplant $E T$ and mean daily $E T\left(E T_{d}\right)$ at different growth stages for different deficit irrigation treatments. $E T$ and $E T_{d}$ for the whole-growth stages were similar during two seasons, whereas the values of $E T$ and $E T_{d}$ in 2017 were lower at stage 1 and higher at stage 3 than those in 2018. The possible reason may be that higher air temperature during stage 1 in 2018 and stage 3 in 2017 caused greater water consumption (Table 1). ET for full irrigation at stage 2 was higher and accounted for $49 \%$ (2017) and 52\% (2018) of the total $E T$ for the whole-growth stages. ET values for deficit irrigation at stages 2 and 3 were significantly lower than those for full irrigation, and greater deficit irrigation led to lower $E T$. ET values for treatments $\mathrm{T}_{5}$ and $\mathrm{T}_{8}$ were less than the values for full irrigation by $\approx 29 \%$ and $53 \%$ in 2017 and by $25 \%$ and $48 \%$ in 2018 . These results are consistent with those of many previous studies (Chen et al., 2013, 2014; Topcu et al., 2007; Wang et al., 2015). The effects of water deficit for stage 2 on $E T$ were greater than those for stage 3. $E T$ values for treatments $\mathrm{T}_{1}$ and $\mathrm{T}_{2}$ were less than those for CK by $\approx 19 \%$ and $36 \%$ in 2017 and by $19 \%$ and $30 \%$ in 2018 . $E T$ values for $\mathrm{T}_{3}$ and $\mathrm{T}_{4}$ were less than those for $\mathrm{CK}$ by $\approx 10 \%$ and $22 \%$ in 2017 and by $10 \%$ and $11 \%$ in 2018 .

Effects of deficit irrigation on fruit yield parameters and water use efficiency. Consecutive deficit irrigation treatments during stages 2 and 3 resulted in significantly decreased tomato whole-plant yield $(Y)$, and higher deficit irrigation levels led to decreased $Y$ values (Table 4). The highest $Y$ values occurred during treatment CK (202.9 and $252.20 \mathrm{~g} /$ plant in 2017 and 2018). The $Y$ value was less than the $\mathrm{CK}$ value by $\approx 42 \%$ to $73 \%$ and by $89 \%$ to $90 \%$ for treatments $\mathrm{T}_{5}$ and $\mathrm{T}_{8}$ in 2017 and 2018, respectively. These results are similar to those of other studies
Table 4. Effects of water deficit at different growing stages on yield parameters and water use efficiency $(W U E)$ for two seasons.

\begin{tabular}{lcccccc}
\hline $\begin{array}{l}\text { Crop } \\
\text { season }\end{array}$ & Treatment & $\begin{array}{c}\text { Yield } \\
(\mathrm{g})\end{array}$ & $\begin{array}{c}\text { Single fruit } \\
\text { wt }(\mathrm{g})\end{array}$ & $\begin{array}{c}\text { Diam } \\
(\mathrm{mm})\end{array}$ & $\begin{array}{c}\text { Length } \\
(\mathrm{mm})\end{array}$ & $\begin{array}{c}W U E \\
\left(\mathrm{~kg} / \mathrm{m}^{3}\right)\end{array}$ \\
\hline 2017 & $\mathrm{~T}_{1}$ & $200.83 \mathrm{a}$ & $23.62 \mathrm{a}$ & $36.18 \mathrm{~b}$ & $35.40 \mathrm{a}$ & $21.36 \mathrm{a}$ \\
& $\mathrm{T}_{2}$ & $93.40 \mathrm{~d}$ & $20.76 \mathrm{~b}$ & $24.27 \mathrm{~d}, \mathrm{e}$ & $28.51 \mathrm{~b}, \mathrm{c}$ & $12.54 \mathrm{~d}$ \\
& $\mathrm{~T}_{3}$ & $134.24 \mathrm{~b}$ & $22.37 \mathrm{c}$ & $31.26 \mathrm{c}$ & $31.72 \mathrm{~b}$ & $12.81 \mathrm{c}, \mathrm{d}$ \\
& $\mathrm{T}_{4}$ & $124.43 \mathrm{c}$ & $18.83 \mathrm{~d}$ & $35.87 \mathrm{~b}$ & $31.54 \mathrm{~b}$ & $13.69 \mathrm{c}$ \\
& $\mathrm{T}_{5}$ & $54.62 \mathrm{e}$ & $16.29 \mathrm{e}$ & $29.96 \mathrm{c}$ & $29.82 \mathrm{~b}$ & $12.14 \mathrm{~d}$ \\
& $\mathrm{~T}_{6}$ & $20.79 \mathrm{~g}$ & $18.83 \mathrm{~d}$ & $21.93 \mathrm{f}$ & $21.88 \mathrm{e}$ & $9.37 \mathrm{e}$ \\
& $\mathrm{T}_{7}$ & $42.15 \mathrm{f}$ & $14.26 \mathrm{e}$ & $26.06 \mathrm{~d}$ & $25.56 \mathrm{~d}$ & $6.13 \mathrm{f}$ \\
& $\mathrm{T}_{8}$ & $18.39 \mathrm{~g}$ & $7.49 \mathrm{f}$ & $23.16 \mathrm{e}, \mathrm{f}$ & $25.65 \mathrm{~d}$ & $3.35 \mathrm{~g}$ \\
& $\mathrm{CK}^{2018}$ & $202.9 \mathrm{a}$ & $25.53 \mathrm{a}$ & $45.88 \mathrm{a}$ & $36.5 \mathrm{a}$ & $17.48 \mathrm{~b}$ \\
& $\mathrm{~T}_{1}$ & $236.88 \mathrm{a}$ & $27.84 \mathrm{a}, \mathrm{b}$ & $38.31 \mathrm{a}$ & $33.13 \mathrm{a}$ & $25.08 \mathrm{a}$ \\
& $\mathrm{T}_{2}$ & $118.92 \mathrm{e}$ & $21.99 \mathrm{c}$ & $31.66 \mathrm{~b}$ & $29.43 \mathrm{~b}$ & $14.60 \mathrm{~d}, \mathrm{e}$ \\
& $\mathrm{T}_{3}$ & $185.18 \mathrm{~b}$ & $26.05 \mathrm{~b}$ & $36.06 \mathrm{a}$ & $32.76 \mathrm{a}, \mathrm{b}$ & $17.65 \mathrm{c}$ \\
& $\mathrm{T}_{4}$ & $176.29 \mathrm{c}$ & $18.68 \mathrm{e}$ & $29.36 \mathrm{c}, \mathrm{d}$ & $29.23 \mathrm{~b}$ & $17.12 \mathrm{c}$ \\
& $\mathrm{T}_{5}$ & $145.12 \mathrm{~d}$ & $20.08 \mathrm{~d}, \mathrm{e}$ & $31.21 \mathrm{~b}$ & $27.73 \mathrm{c}$ & $16.72 \mathrm{~d}$ \\
& $\mathrm{~T}_{6}$ & $93.80 \mathrm{e}$ & $21.47 \mathrm{c}$ & $28.96 \mathrm{c}$ & $28.28 \mathrm{~b}, \mathrm{c}$ & $11.40 \mathrm{e}$ \\
& $\mathrm{T}_{7}$ & $55.37 \mathrm{f}$ & $15.92 \mathrm{f}$ & $26.63 \mathrm{~d}$ & $26.05 \mathrm{~d}$ & $7.75 \mathrm{f}$ \\
& $\mathrm{T}_{8}$ & $27.63 \mathrm{~g}$ & $9.27 \mathrm{~g}$ & $20.68 \mathrm{e}$ & $20.35 \mathrm{e}$ & $4.57 \mathrm{~g}$ \\
& $\mathrm{CK}$ & $252.20 \mathrm{a}$ & $28.92 \mathrm{a}$ & $37.73 \mathrm{a}$ & $32.66 \mathrm{a}$ & $21.74 \mathrm{~b}$ \\
\hline
\end{tabular}

Data followed by different letters for each season are significantly different at $P<0.05$ according to Duncan's multiple range tests. 
(Chen et al., 2013, 2014; Jensen et al., 2010; Topcu et al., 2007; Wang et al., 2015). A significant reduction in $Y$ was observed with all water deficit treatments at stage 2 or stage 3 during both seasons, except $\mathrm{T}_{1} . Y$ decreased by $\approx 53 \%$ to $54 \%$ and by $30 \%$ to $39 \%$ with treatments $T_{2}$ and $T_{4}$ when compared with $\mathrm{CK}$, and severe deficit irrigation at stage 2 resulted in lower $Y$ than that at stage 3 . The same severe reduction in yield has been found by many studies (Chen et al., 2014; Favati et al., 2009; Patanè and Cosentino,
2010; Patanè et al., 2011; Pernice et al., 2010). There was no significant difference in $Y$ between $\mathrm{T}_{1}$ and CK treatments, probably because the reduction to $2 / 3$ of the full irrigation amount at stage 2 was not a great enough deficit to affect the yield. Chen et al.
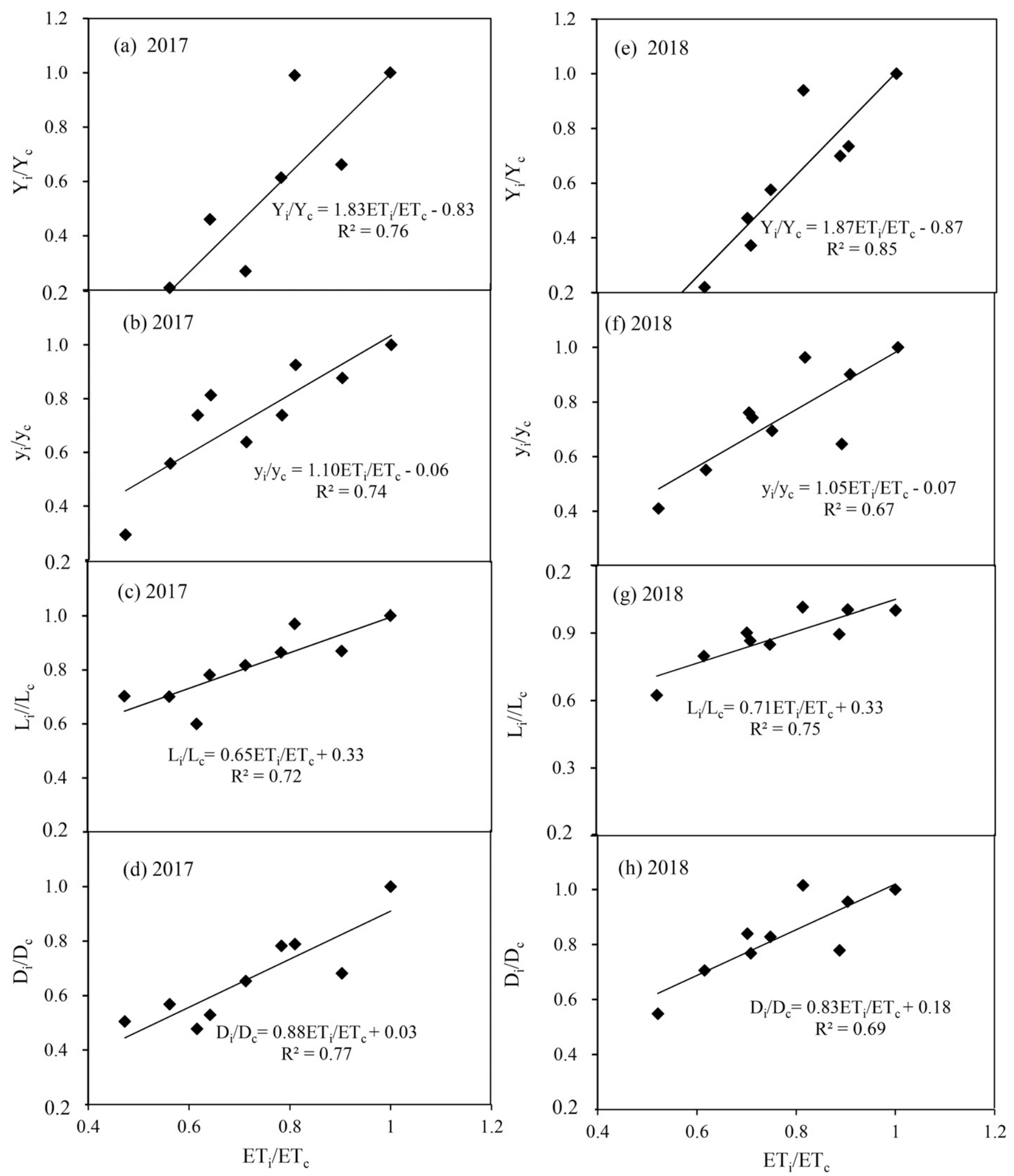

Fig. 1. Relationships between relative whole-plant yield $\left(Y_{i} / Y_{c}\right)$, single-fruit weight $\left(y_{i} / y_{c}\right)$, single-fruit length $\left(L_{i} / L_{c}\right)$, and single-fruit diameter $\left(D_{i} / D_{c}\right)$ and relative evapotranspiration $\left(E T_{i} / E T_{c}\right)$ in $2017(\mathbf{A}-\mathbf{D})$ and $2018(\mathbf{E}-\mathbf{H})$. 
(2014) also found that the reduction to $2 / 3$ full irrigation at stage 2 had no significant effects on yield.

The single-fruit weight $(y)$, single-fruit diameter $(D)$, and single-fruit length $(L)$ of tomatoes are shown in Table 4. Consecutive deficit irrigation applications significantly decreased $y, D$, and $L$. The highest values of $y, D$, and $L$ were obtained with treatments CK and $\mathrm{T}_{1}$, and the lowest values were obtained with $\mathrm{T}_{8}$. Deficit irrigation treatments during each growth stage, except $\mathrm{T}_{1}$, reduced $y, D$, and $L$ when compared with CK. These results are consistent with those of previous studies (Kirda et al., 2004; Kuscu et al., 2014; Zheng et al., 2013). The responses of $y, D$, and $L$ to deficit irrigation were similar to that of $Y$, which indicated that reductions in $y, D$, and $L$ under water deficit conditions directly result in a reduction in $Y$. Some studies have shown that water deficit at any growth stage does not decrease fruit numbers per plant, but it does significantly decrease the weight per fruit (Chen et al., 2013; Mitchell et al., 1991).

Deficit irrigation significantly affected WUE. Treatment $\mathrm{T}_{1}$ produced the greatest $W U E$, with values of 21.36 and $25.08 \mathrm{~kg} / \mathrm{m}^{3}$ in 2017 and 2018, and treatment $\mathrm{T}_{8}$ produced the lowest $W U E$, with values of 3.35 and $4.57 \mathrm{~kg} / \mathrm{m}^{3}$ in 2017 and 2018, respectively (Table 4). The range of $W U E$ values agreed with values previously found for tomato crops. Wang et al. (2007) found a WUE range of 15.5 to $25.3 \mathrm{~kg} / \mathrm{m}^{3}$ in the North China Plain. Mukherjee et al. (2010) found a $W U E$ range of 13.6 to $27.2 \mathrm{~kg} / \mathrm{m}^{3}$ in India. Kuscu et al. (2014) found a $W U E$ range of 10.5 to $21.4 \mathrm{~kg} / \mathrm{m}^{3}$ in a sub-humid region. We found that, except for $\mathrm{T}_{1}, W U E$ showed a significant decreasing trend when the water deficit increased. This was mainly because deficit irrigation significantly decreased plant yield (Table 4). Therefore, a moderate water deficit at stage 2 can result in both high $W U E$ and high yield.

Relationship between fruit yield parameters and deficit irrigation. Figure 1 shows the relationships between relative seasonal $E T$ $\left(E T_{i} / E T_{c}\right)$ and relative whole-plant yield $\left(Y_{i} /\right.$ $\left.Y_{c}\right)$, relative single-fruit weight $\left(y_{i} / y_{c}\right)$, relative fruit diameter $\left(D_{i} / D_{c}\right)$, and relative fruit length $\left(L_{i} / L_{c}\right) . Y_{i} / Y_{c}$ increased linearly as $E T_{i} / E T_{c}$ increased, with coefficients of determination of $R^{2}=0.76(2017)$ and $R^{2}=$ 0.85 (2018) (Fig. 1A and E). Some studies have shown a positive linear correlation between tomato yield and irrigation water and between relative yield and relative seasonal ET (Chen et al., 2013; Hanson and May, 2004; Zheng et al., 2013). Similar results have been found for other crops (Karam et al., 2007; Qiu et al., 2017; Sezen et al., 2008). The other yield parameters, $y_{i} / y_{c}$, $D_{i} / D_{c}$, and $L_{i} / L_{c}$, also showed good linear relationships with $E T_{i} / E T_{c}$, with high $R^{2}$ (Fig. 1B-D and $\mathrm{F}-\mathrm{H}$ ), mainly because $y$, $D$, and $L$ behaved similarly to $Y$ in response to deficit irrigation.

Water deficit sensitivity indexes and performance of water-yield models. Table 5 shows the water deficit sensitivity indexes $(A, B, C, \lambda, \gamma$, and $\delta$ ) at different growth stages for the Blank, Stewart, Singh, Jensen, Rao, and Minhas models. The experimental data in 2017 were used to calculate the sensitivity indexes using multiple linear regression. The $R^{2}$ showed that all models provided good predictions of the deficit sensitivity indexes $Y, y, D$, and $L$. For $Y$, the performance of the models was ranked as follows: Stewart $>$ Jensen $>$ Minhas $>$ Blank $>$ Singh $>$ Rao. For $y, D$, and $L$, the Blank and Singh models performed better than the others, and the Rao model had the worst performance. The water deficit sensitivity indexes quantify the sensitivity of tomato yield to water deficit at different growth stages, with higher values indicating greater sensitivity (Chen et al., 2014). We found that all the models provided similar results. Higher water deficit sensitivity indexes for $Y, y, D$, and $L$ were found at stage 2 . Sensitivity index values at stage 3 were lower than those at stage 2, which implied that tomato yield parameters were more sensitive to water deficit at stage 2 than that at stage 3 . This is because this stage of fruit growth has the most influence on improving the fruit yield (Nuruddin et al., 2003; Rudich et al., 1977).

The 2018 data were used to validate the water-yield models and their water deficit sensitivity indexes. Figures $2-5$ show comparisons between observed tomato yield parameters and the values predicted by the Blank, Stewart, Singh, Jensen, Rao, and Minhas models. $Y$ values calculated by the Stewart and Minhas models were similar to the observed values of $Y$, with high $R^{2}$ and modified coefficient of efficiency $\left(\mathrm{E}_{1}\right)$ and low RMSE and MAE (Table 5). $Y$ values calculated by the Blank, Singh, Jensen, and Rao models were lower than the observed values (Fig. 2). The Minhas model performed best, and the results it provided were similar to those of Chen et al. (2014), who found that the Minhas model provided the best estimates of tomato water-yield relationships. There was good agreement between the estimated and observed values of $y$ and $L$ for all models $\left(R^{2}=0.38-0.88\right)$ (Figs. 3 and 5; Table 5). For all models, the Blank, Stewart, and Minhas models provided more accurate $y$ values, with lower RMSE and MAE and higher $E_{1}$ and $R^{2}$

Table 5. Water deficit sensitivity indexes and statistical test results for tomato yield parameters predicted by the Blank, Stewart, Singh, Jensen, Rao, and Minhas models compared with the observed yield parameters for two seasons.

\begin{tabular}{|c|c|c|c|c|c|c|c|c|c|}
\hline \multirow[b]{2}{*}{ Yield parameters } & \multirow[b]{2}{*}{ Model } & \multicolumn{3}{|c|}{ Sensitivity index $(A / B / C / \lambda / \gamma / \delta)$} & \multicolumn{5}{|c|}{ Fit indicators } \\
\hline & & Stage 2 & Stage 3 & $R^{2}$ & $a$ & MAE & RMSE & $E_{1}$ & $R^{2}$ \\
\hline \multirow[t]{6}{*}{ Whole-plant yield } & Blank & 0.23 & 0.54 & 0.87 & 0.85 & 38.67 & 42.86 & 0.37 & 0.25 \\
\hline & Stewart & 0.56 & 1.10 & 0.95 & 0.91 & 16.72 & 22.56 & 0.73 & 0.94 \\
\hline & Singh & 0.20 & 0.41 & 0.79 & 0.78 & 50.59 & 59.05 & 0.18 & 0.08 \\
\hline & Jensen & 0.82 & 1.74 & 0.93 & 0.81 & 29.77 & 47.53 & 0.52 & 0.75 \\
\hline & Rao & 0.71 & 1.24 & 0.75 & 0.88 & 18.51 & 25.93 & 0.70 & 0.90 \\
\hline & Minhas & 1.95 & 4.04 & 0.92 & 0.94 & 11.071 & 15.08 & 0.82 & 0.98 \\
\hline \multirow[t]{6}{*}{ Single-fruit weight } & Blank & 0.41 & 0.65 & 0.97 & 0.99 & 1.77 & 2.29 & 0.99 & 0.80 \\
\hline & Stewart & 0.34 & 0.53 & 0.86 & 0.99 & 1.80 & 2.34 & 0.99 & 0.69 \\
\hline & Singh & 0.40 & 0.47 & 0.97 & 0.98 & 2.87 & 3.22 & 0.98 & 0.38 \\
\hline & Jensen & 0.39 & 0.51 & 0.81 & 0.95 & 2.33 & 3.08 & 0.98 & 0.65 \\
\hline & Rao & 0.37 & 0.56 & 0.53 & 0.99 & 2.02 & 2.48 & 0.98 & 0.60 \\
\hline & Minhas & 0.94 & 1.17 & 0.82 & 1.01 & 1.88 & 2.83 & 0.98 & 0.73 \\
\hline \multirow[t]{6}{*}{ Diameter } & Blank & 0.45 & 0.51 & 0.98 & 0.83 & 5.68 & 6.15 & 0.95 & 0.82 \\
\hline & Stewart & 0.46 & 0.56 & 0.96 & 0.87 & 4.28 & 4.92 & 0.96 & 0.82 \\
\hline & Singh & 0.18 & 0.60 & 0.98 & 0.82 & 5.28 & 5.94 & 0.95 & 0.56 \\
\hline & Jensen & 0.44 & 0.50 & 0.94 & 0.86 & 4.93 & 5.73 & 0.96 & 0.69 \\
\hline & Rao & 0.55 & 0.61 & 0.79 & 0.85 & 5.08 & 5.89 & 0.96 & 0.72 \\
\hline & Minhas & 1.03 & 1.11 & 0.89 & 0.92 & 3.74 & 4.76 & 0.97 & 0.73 \\
\hline \multirow[t]{6}{*}{ Length } & Blank & 0.35 & 0.80 & 0.98 & 0.93 & 3.35 & 3.86 & 0.97 & 0.71 \\
\hline & Stewart & 0.15 & 0.45 & 0.91 & 0.94 & 1.96 & 2.33 & 0.98 & 0.79 \\
\hline & Singh & 0.31 & 0.64 & 0.99 & 0.94 & 1.75 & 2.10 & 0.98 & 0.88 \\
\hline & Jensen & 0.14 & 0.37 & 0.89 & 0.93 & 2.47 & 3.36 & 0.98 & 0.65 \\
\hline & Rao & 0.17 & 0.47 & 0.68 & 0.93 & 2.17 & 2.52 & 0.98 & 0.79 \\
\hline & Minhas & 0.39 & 0.80 & 0.86 & 0.97 & 1.40 & 1.67 & 0.99 & 0.88 \\
\hline
\end{tabular}

$\overline{R^{2}}=$ coefficient of determination; $a=$ slope of the linear regression equation; MAE $=$ mean absolute error; RMSE $=$ root mean square error; $\mathrm{E}_{1}=$ modified coefficient of efficiency. 

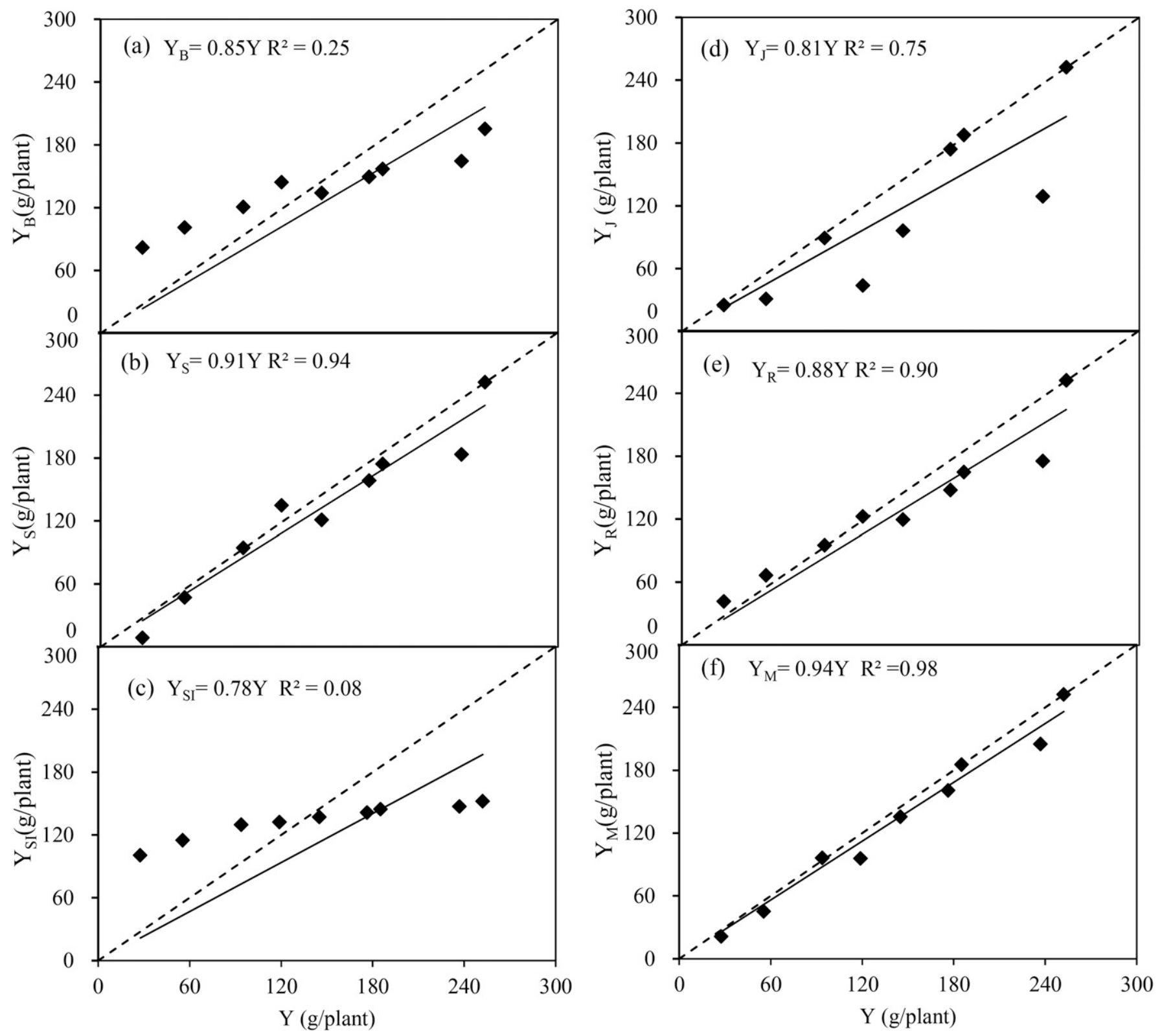

Fig. 2. Comparison of tomato whole-plant yield predicted by the Blank $\left(Y_{B}\right)$, Stewart $\left(Y_{S}\right)$, Singh $\left(Y_{S I}\right)$, Jensen $\left(Y_{J}\right)$, Rao $\left(Y_{R}\right)$, and Minhas $\left(Y_{M}\right)$ models with the observed yield $(Y)$ in 2018.

values, whereas the Singh model showed a low $R^{2}$ value. The Minhas model provided the most accurate $L$ value, the lowest RMSE and MAE values, and the highest $\mathrm{E}_{1}$ and $R^{2}$ values. The predicted $\mathrm{D}$ was only $8 \%$ less than the observed $D$ for the Minhas model (Fig. 4). $D$ values calculated by the Blank, Stewart, Singh, Jensen, and Rao models were significantly less than the observed $D$ values.

\section{Conclusions}

The results showed that deficit irrigation at each growth stage significantly reduced tomato whole-plant $E T$, whole-plant $Y$, single-fruit $y$, fruit $D$, fruit $L$, and $W U E$, except for $\mathrm{T}_{1}$ (receiving $2 / 3$ full irrigation at flowering and fruit development), which produced higher $W U E$ without a significant reduction in yield. These results showed that a balance between improved WUE and acceptable yield can be obtained with an appropriate water deficit at stage 2 . Relative $Y, y, D$, and $L$ increased linearly as relative seasonal $E T$ increased. The water deficit sensitivity indexes for the six water-yield models showed that the plants were more sensitive to water deficit at stage 2 than that at stage 3 . Predicted $Y$ values calculated by the Stewart and Minhas models were similar to observed values, and those calculated by the Blank, Singh, Jensen, and Rao models were less than the observed values. The six water-yield models predicted $y$ and $L$ accurately, with the Blank model ranking first for $y$ and the Minhas model ranking first for $L$. The best prediction of $D$ was provided by the Minhas model, which yielded a value only $8 \%$ less than the observed value. Predicted values of $D$ provided by the by Blank, Stewart, Singh,
Jensen, and Rao models were significantly less than the observed values. The wateryield models are useful for optimizing irrigation water management and provide a sound basis for the efficient production of tomato crops.

\section{Literature Cited}

Blank, H. 1975. Optimal irrigation decisions with limited water: [PhD Thesis]. Colorado State University, Fort Collins, CO.

Chen, J., S. Kang, T. Du, P. Guo, R. Qiu, R. Chen, and F. Gu. 2014. Modeling relations of tomato yield and fruit quality with water deficit at different growth stages under greenhouse condition. Agr. Water Mgt. 146:131-148.

Chen, J., S. Kang, T. Du, R. Qiu, P. Guo, and R. Chen. 2013. Quantitative response of greenhouse tomato yield and quality to water deficit at different growth stages. Agr. Water Mgt. 129(11):152-162. 

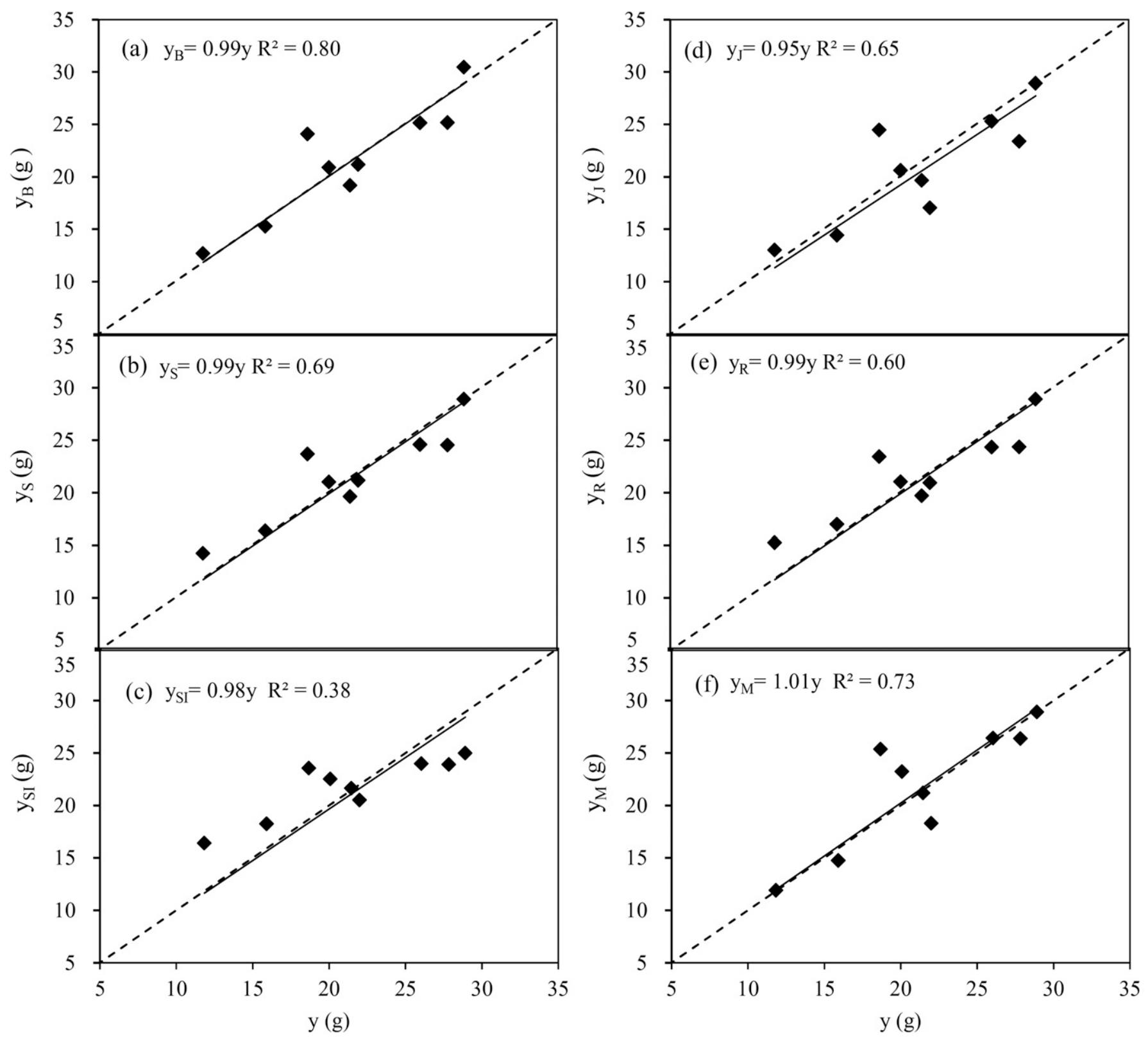

Fig. 3. Comparison of tomato single-fruit weight predicted by the Blank $\left(y_{B}\right)$, Stewart $\left(y_{S}\right)$, Singh $\left(y_{S I}\right)$, Jensen $\left(y_{J}\right)$, Rao $\left(y_{R}\right)$, and Minhas $\left(y_{M}\right)$ models with the observed single-fruit weight $(y)$ in 2018.

Doorenbos, J. and A.H. Kassam. 1979. Yield response to water. United Nations FAO Publication no. 33, Rome.

Favati, F., S. Lovelli, F. Galgano, V. Miccolis, T. Di Tommaso, and V. Candido. 2009. Processing tomato quality as affected by irrigation scheduling. Scientia Hort. 122:562-571.

Giuliani, M.M., G. Gatta, E. Nardella, and E. Tarantino. 2016. Water saving strategies assessment on processing tomato cultivated in Mediterranean region. Ital. J. Agron. 11:69-76.

Hanson, B.R., R.B. Hutmacher, and D.M. May. 2006. Drip irrigation of tomato and cotton under shallow saline ground water conditions. Irrig. Drain. Syst. 20(2-3):155-175.

Ho, L.C. 1996. Tomato, p. 709-728. In: E. Zemaski and A.A. Schaffer (eds.). Photo assimilate distribution in plants and crops: Source-sink relationships. Marcel Dekker, New York, NY.

Igbadun, H.E., A.K.P.R. Tarimo, B.A. Salim, and H.F. Mahoo. 2007. Evaluation of selected crop water production functions for an irrigated maize crop. Agr. Water Mgt. 94:1-10.
Jensen, M.E. 1968. Water consumption by agricultural plants, p. 1-22. In: T.T. Kozlowski (ed.) Water deficits in plant growth. Academic Press, New York, NY.

Jensen, C.R., A. Battilani, F. Plauborg, G. Psarras, K. Chartzoulakis, F. Janowiak, R. Sti-kic, Z. Jovanovic, G.T. Li, X.B. Qi, F.L. Liu, S.E. Jacobsen, and M.N. Andersen. 2010. Deficit irrigation based on drought tolerance and root signaling in potatoes and tomatoes. Agr. Water Mgt. 98:403-413.

Karam, F., R. Lahoud, R. Masaad, R. Kabalan, J. Breidi, C. Chalita, and Y. Rouphael. 2007. Evapotranspiration, seed yield and water use efficiency of drip irrigated sunflower under full and deficit irrigation conditions. Agr. Water Mgt. 90:213-223.

Kirda, C., M. Cetin, Y. Dasgan, S. Topcu, H. Kaman, B. Ekici, M.R. Derici, and A.I. Ozguven. 2004. Yield response of greenhouse grown tomato to partial root drying and conventional deficit irrigation. Agr. Water Mgt. 69:191-201.
Kuscu, H., A. Turhan, and A.O. Demir. 2014. The response of processing tomato to deficit irrigation at various phonological stages in a sub-humid environment. Agr. Water Mgt. 133:92-103.

Legates, D.R. and G.J. McCabe. 1999. Evaluating the use of "goodness-of-fit" measures in hydrologic and hydroclimatic model validation. Water Resour. Res. 35:233-241.

Li, X., L. Tong, S. Kang, and F. Li. 2011. Comparison of spatial interpolation methods for yield response factor of winter wheat and its spatial distribution in Haihe basin of north China. Irrig. Sci. 29(6):455-468.

Marouelli, W.A. and W.L.C. Silva. 2007. Water tension thresholds for processing tomatoes under drip irrigation in Central Brazil. Irrig. Sci. 25:411-418.

Minhas, B., K. Parikh, and T. Srinivasan. 1974. Toward the structure of a production function for wheat yields with dated inputs of irrigation water. Water Resour. Res. 10(3):383-393.

Mitchell, J.P., C. Shennan, S.R. Grattan, and D.M. May. 1991. Tomato fruit yield and quality 

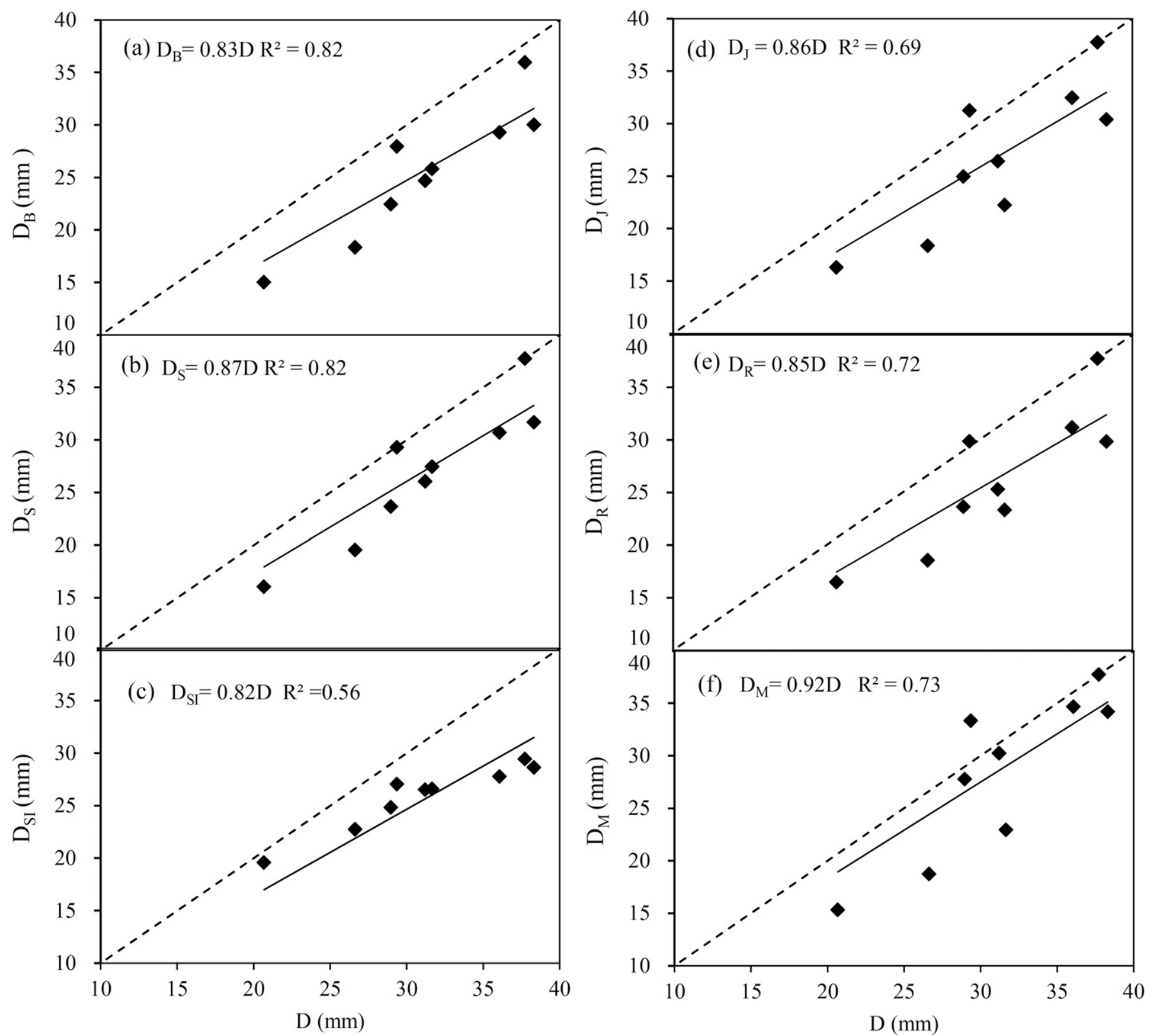

Fig. 4. Comparison of tomato fruit diameter predicted by the Blank $\left(D_{B}\right)$, Stewart $\left(D_{S}\right)$, Singh $\left(D_{S I}\right)$, Jensen $\left(D_{J}\right)$, Rao $\left(D_{R}\right)$, and Minhas $\left(D_{M}\right)$ models with the observed fruit diameter $(D)$ in 2018.

under water deficit and salinity. J. Amer. Soc. Hort. Sci. 116:215-221.

Mukherjee, A., M. Kundu, and S. Sarkar. 2010 Role of irrigation and mulch on yield, evapotranspiration rate and water use pattern of tomato (Lycopersicon esculentum L.). Agr. Water Mgt. 98:182-189.

Nuruddin, M.M., C.A. Madramootoo, and G.T. Dodds. 2003. Effects of water stress at different growth stages on greenhouse tomato yield and quality. HortScience 38:1389-1393.

Paredes, P., G.C. Rodrigues, I. Alves, and L.S Pereira. 2014. Partitioning evapotranspiration, yield prediction and economic returns of maize under various irrigation management strategies. Agr. Water Mgt. 135:27-39.

Parry, M.A.J., J. Flexas, and H. Medrano. 2005. Prospects for crop production under drought: Research priorities and future directions. Ann. Appl. Biol. 147:211-226.

Patanè, C. and S.L. Cosentino. 2010. Effects of soil water deficit on yield and quality of processing tomato under a Mediterranean climate. Agr. Water Mgt. 97:131-138.

Patanè, C., S. Tringali, and O. Sortino. 2011. Effect of deficit irrigation on biomass, yield, water use efficiency a fruit quality of processing tomato under semi-arid Mediterranean climate conditions. Scientia Hort. 129(4):590-596.

Pereira, L.S., T. Oweis, and A. Zairi. 2002. Irrigation management under water scarcity. Agr. Water Mgt. 57:175-206.

Pernice, R., M. Parisi, I. Giordano, A. Pentangelo, G. Graziani, M. Gallo, V. Fogliano, and A. Ritieni. 2010. Antioxidants profile of small tomato fruits: Effects of irrigation and industrial process. Scientia Hort. 126:156-163.

Pulupol, L.U., M.H. Behboudian, and K.J. Fisher. 1996. Growth, yield and postharvest attributes of glasshouse tomatoes produced under water deficit. HortScience 31:926-929.

Qiu, R., Y. Jing, C. Liu, Z. Yang, and Z.C. Wang. 2017. Response of hot pepper yield, fruit quality and fruit ion content to irrigation water salinity and leaching fractions. HortScience 52:979-985.

Qiu, R., Z. Yang, Y. Jing, C. Liu, X. Luo, and Z. Wang. 2018. Effects of irrigation water salinity on the growth, gas exchange parameters, and ion concentration of hot pepper plants modified by leaching fractions. HortScience 53:10501055 .

Rao, N., P. Sarma, and S. Chander. 1988. A simple dated water-production function for use in irrigated agriculture. Agr. Water Mgt. 13(1):25-32.

Renquist, A.R. and J.B. Reid. 2001. Processing tomato fruit quality: Influence of soil water deficits at flowering and ripening. Austral. J Agr. Res. 52:793-799.

Rudich, J., D. Kalmar, C.C. Geizenberg, and S. Harsel. 1977. Low water tension in defined growth stages of processing tomato plants and their effects on yield and quality. J. Hort. Sci. 52:391-399.

Sezen, S.M., A. Yazar, A. Asiye, H.Y. Dasgan, and B. Gencel. 2008. Yield and quality response of 

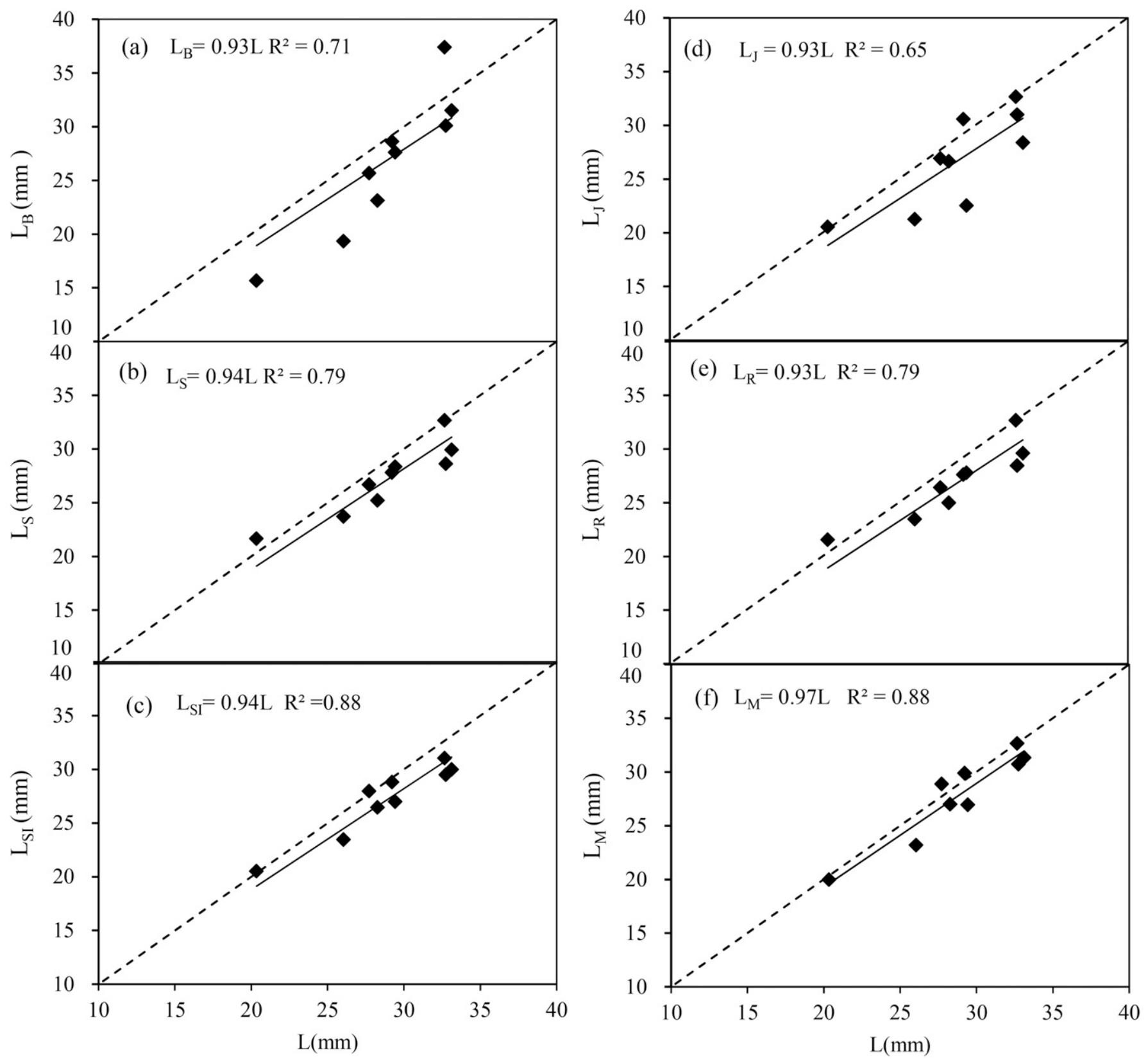

Fig. 5. Comparison of tomato fruit length predicted by the Blank $\left(L_{B}\right)$, Stewart $\left(L_{S}\right)$, Singh $\left(L_{S I}\right)$, Jensen $\left(L_{J}\right)$, Rao $\left(L_{R}\right)$, and Minhas $\left(L_{M}\right)$ models with the observed fruit length $(L)$ in 2018.

drip irrigated green beans under full and deficit irrigation. Scientia Hort. 117:95-102.

Singh, P., H. Wolkewitz, and R. Kumar. 1987. Comparative performance of different crop production functions for wheat (Triticum aestivum L.). Irrig. Sci. 8(4):273-290.

Stewart, J.I., R.H. Cuenca, W.O. Pruit, R.M. Hagan, and J. Tosso. 1977. Determination and utilization of water production functions for principal California crops. W-67 California Contribution Project Report. University of California, Davis, CA.

Stewart, J., R. Hagan, and W. Pruitt. 1976. Production functions and predicted irrigation programmes for principal crops as required for water resources planning and increased water use efficiency. Final Report. Department of Interior, Washington, D.C.

Topcu, S., C. Kirda, Y. Dasgan, H. Kaman, M. Cetin, A. Yazici, and M.A. Bacon. 2007. Yield response and $\mathrm{N}$-fertiliser recovery of tomato grown under deficit irrigation. Eur. J. Agron. 26:64-70.

Wang, C., F. Gu, J. Chen, H. Yang, J. Jiang, T. Du, and J. Zhang. 2015. Assessing the response of yield and comprehensive fruit quality of tomato grown in greenhouse to deficit irrigation and nitrogen application strategies. Agr. Water Mgt. 161(5):9-19.

Wang, D., Y. Kang, and S. Wan. 2007. Effect of soil matric potential on tomato yield and water use under drip irrigation condition. Agr. Water Mgt. 87:180-186.

Wang, F., T. Du, R. Qiu, and G. Dong. 2011a. Effects of water stress at different growth stage on greenhouse multiple-trusses tomato yield and quality. International Conference on Agricultural Engineering New Technology and Taishan Academic Forum.

Wang, F., S. Kang, T. Du, F. Li, and R. Qiu. 2011b. Determination of comprehensive quality index for tomato and its response to different irriga- tion treatments. Agr. Water Mgt. 98(8):12281238 .

Xu, S.Z., S.B. Zhang, J.Q. Lu, and J.B. Jin. 2001. Research on water consumption pattern and water production function of greenhouse tomato under drip irrigation. Water Sav. Irrig. 4:26-28.

Zhang, H. and T. Oweis. 1999. Water-yield relations and optimal irrigation scheduling of wheat in the Mediterranean region. Agr. Water Mgt. 38:195-211.

Zhang, H., X. Wang, M. You, and C. Liu. 1999. Water-yield relations and water use efficiency of winter wheat in the North China Plain. Irrig. Sci. 19:37-45.

Zheng, J., G. Huang, D. Jia, J. Wang, M. Mota, L.S. Pereira, Q. Huang, X. Xu, and H. Liu. 2013. Responses of drip irrigated tomato (Solanum lycopersicum $L$.) yield, quality and water use efficiency to various soil matric potential thresholds in an arid region of Northwest China. Agr. Water Mgt. 129:181-193. 